\title{
Transformative Study Abroad and the Development of Preservice Teachers' Culturally Competent Pedagogy as Action Toward a Re-Imagined Future
}

\author{
Allison Freed \\ University of the Ozarks \\ Aerin Benavides \\ University of North Carolina at Greensboro \\ Lacey D. Huffling \\ Georgia Southern University
}

We examine the long-term impacts of teacher education study abroad on students' culturally competent pedagogy and their actions toward a re-imagined future. This longitudinal study includes teachers who participated in a short-term undergraduate study abroad in the Netherlands or Peru (N=93). Our five case studies show an increase in their cultural awareness. They leveraged their experiences by sharing stories with their students, using learned cultural competency skills to understand their students' lived experiences, and engaged in critical reflection. As teacher educators and researchers, our responsibility is to guide our students in culturally competent pedagogical action toward re-imagined futures.

Keywords: transformational learning, cultural competence, study abroad, teacher education, critical pedagogy of place

\section{INTRODUCTION}

Education students make up only $3.3 \%$ of the total students that study abroad in higher education, according to the 2017-2018 data (IIE, 2020). This low number is caused by extensive program requirements, as well as a view that study abroad does not increase job prospects (Cavanaugh \& Corbett, 2014). However, research has also shown that study abroad programs can be successful in increasing cultural awareness and competency (Cavanaugh \& Corbett, 2014; Freed et al, 2019; Medina-Lopez-Portillo, 2004; Chieffo \& Griffiths, 2004; Malewski, Sharma, \& Phillion, 2012). Cultural awareness can be impacted through cultural activities experienced through study abroad programs, which can in turn reveal the assumptions and biases the participants have of the host country. In turn, this newfound awareness can increase students' cultural competence through their understanding of culture and how it impacts communication, social interactions, and others' lived experiences (Addleman, et al., 2014). Furthermore, we define cultural competence as one's ability to be okay with discomfort, to be curious, to ask questions, to reflect, and to critically engage with other cultures as well as their own. We view teacher education study abroad as an opportunity for our students to engage in transformative learning, leading to them being more 
skilled, and culturally competent, which will further transform their pedagogy. We see cultural competence as dynamic and not a linear continuum with a starting and ending point. Rather, one's cultural competence can ebb and flow depending on one's lived experiences and how one continues to critically reflect upon and seek out similar experiences.

Though research supports the positive impacts that teacher education study abroad has on preservice teachers, there is little understanding of the long-term impacts of study abroad on the teaching practices of education majors who elect to participate in short-term study abroad programs. Therefore, we aim to investigate the greater impacts of short-term study abroad on participants actions and behaviors when they arrive home. How are they transformed, changed, and to what extent?

\section{THEORETICAL FRAMEWORK}

Teacher education study abroad experiences can be transformative. Transformative experiences, according to Mezirow (1997) possess certain factors or components. These factors include a disorienting experience, a critical frame of reference, and a change in perspective through thoughtful reflection, prompting future action planning (Freed et al., 2019; Addleman et al., 2014). Transformative teacher education study abroad experiences have long-term effects. These effects influence instruction and dispositions that lead to lasting, positive effects on teachers' cultural awareness and connection to place (Kalina \& Powell, 2009). These long-term impacts assist them in taking pedagogical action to serve all students.

The first component of Transformational Learning Theory, 'disequilibrium triggering and/or disorienting experiences', as Jack Mezirow (1997) described, are triggered by a crisis or critical incident that results in a disorienting dilemma. This trigger may be a discrepancy between what a person experiences in cultural immersion and what they had always assumed to be true (Addleman et al., 2014). This, as Addleman and colleagues described it, means that a single event will not cause disorientation for everyone experiencing it, disorientation depends upon each individual's value systems.

The second component of Transformational Learning Theory, 'being critical to frame of reference', an exercise of critical reflection, helps students to become aware of underlying intentions, values, feelings and beliefs that may not have been recognized before (Mezirow, 1997). A frame of reference, as Mezirow described it, is composed of habits of mind and an existing point of view. While habits of mind are broad and abstract habitual ways of thinking, a point of view is a concrete result. An example of this would be habitually seeing those outside of one's own cultural group as inferior, which results in a point of view that creates an attitude of disdain for or a feeling of superiority over those outside one's group. Frames of reference can be transformed through critical reflection on the assumptions upon which the habits of mind were based, thus possibly transforming those habits of mind and points of view towards a more inclusive frame of reference (Mezirow, 1997).

The third component of Transformational Learning Theory, 'transformative change, plans, actions', is something that, if circumstances permit, the learner moves towards. Cranton (2002) condenses exploring new roles, relationships and the planning of and taking of action into this final transformation component. An individual would in this component act on revisions in their frame of reference, acting, speaking and behaving in congruence with their transformed perspective (Addleman et al., 2014).

Though Transformational Learning Theory can lead to future action planning, we see the need to purposefully provide students with experiences and opportunities that scaffold their ability to critically reflect upon how in our world there exist oppressing race, gender and class as well as ecologically damaging cultural patterns that need to be transformed to contribute to the well-being of people and places, despite people and structures that would conserve them (Gruenewald, 2003). Therefore, we infuse Transformational Learning Theory with Critical Pedagogy of Place (CPP) (Gruenewald, 2003) to facilitate students' process of deciding what needs to be transformed and what does not. CPP emphasizes the spatial aspects of social experience, promotes a deeper understanding of place-based pedagogy, and calls on us to critically decolonize (deconstruct), analyze, and then re-inhabit (re-imagine) place. CPP connects physical place with self, culture, and community. 
Transformational Learning Theory and CPP are mutually supportive of each other and overlap in a critical analysis component. Together, they offer a synchronous path for preservice teachers from triggering transformative experiences, with reflection and analysis, towards becoming culturally competent teachers able to reimagine a better future and take pedagogical action (Figure 1).

\section{FIGURE 1 \\ THEORETICAL FRAMEWORK}

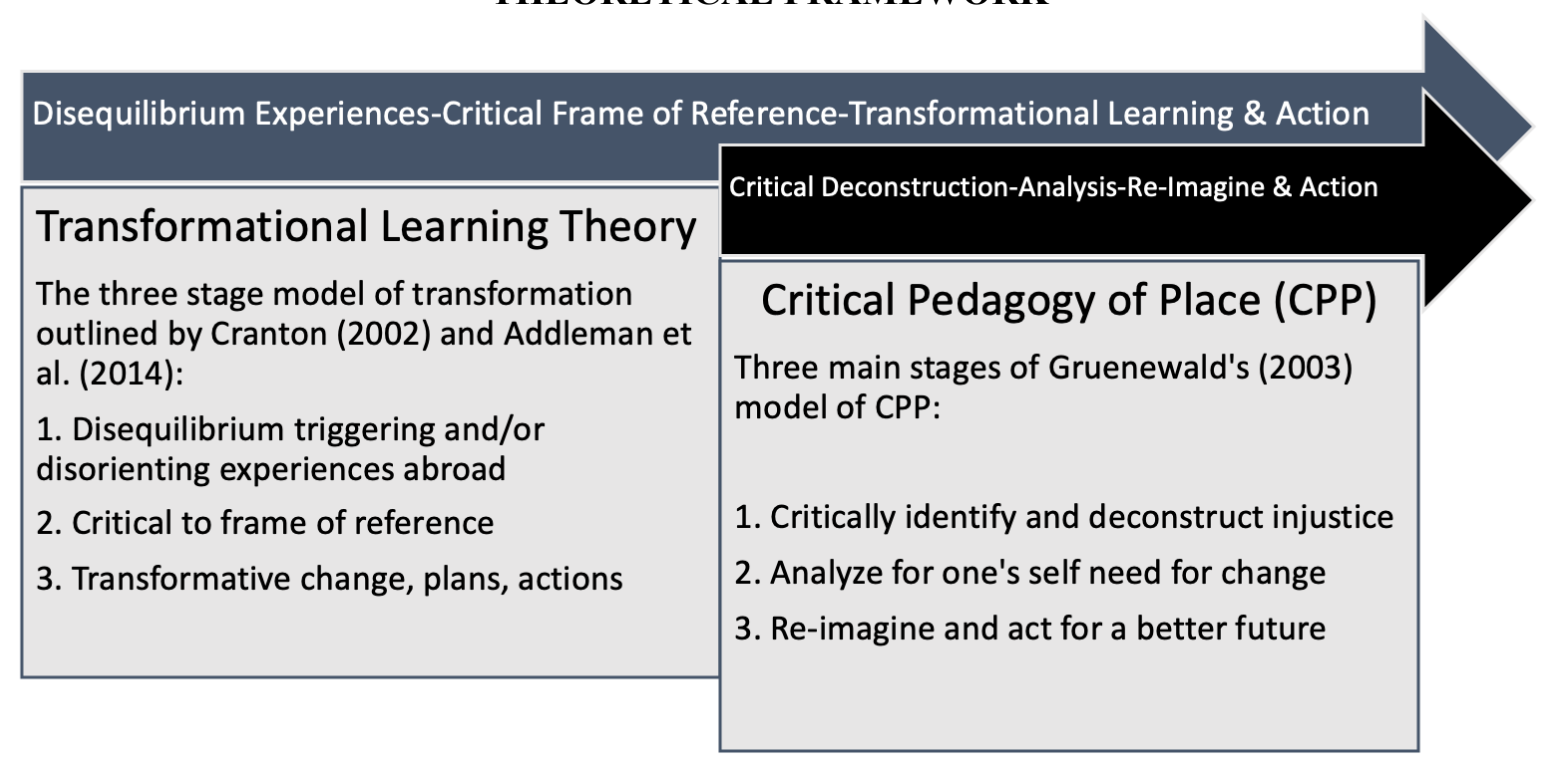

Figure 1. Mutually beneficial elements of Transformational Learning Theory and Critical Pedagogy of Place (CPP) as synchronous study frameworks; adapted from Cranton (2002), Addleman et al. (2014), and Gruenewald (2003).

The purpose of our research is to show how teacher education study abroad can help preservice teachers develop long-term cultural competence skills and in turn take actionable steps toward culturally competent pedagogy. We examine the long-term effects of study abroad on the practices of current in-service teachers using a co-supportive Transformational Learning Theory and CPP theoretical framework. We pose the question about what the expectations should be for action in this framework after studying abroad. In this paper, we also investigate the program components that could have a long-term impact on teaching and taking action in the place teachers call their home/school.

Our research questions are:

- How and in what way do teachers critically reflect upon the transformational effects of their past teacher education study abroad experience?

- How and in what way do teachers use their past teacher education study abroad experience toward an actionable re-imagined future?

\section{METHODOLOGY}

Our longitudinal study includes descriptive participant case studies from two different teacher education study abroad programs: Netherlands and Peru. The Netherlands program was three weeks (2022 days) long with a focus on the cultural aspects of education and the education system, in an international context. Two universities participated in this annual trip over 7 years with a total of 79 students. The Peru trip was 12 days long with a focus on Environmental Education (EE) and educational exchange in cultural immersion with Peruvian scientists, wildlife guides, educators, and schools (K-11). A large public state university in the Southeast instituted this trip as a first time endeavor and most of the 22 student participants were preservice teachers. The two programs, while similar in some aspects, had unique goals, foci, destinations, and assignments (Table 1). 
TABLE 1

PROGRAM DESCRIPTIONS

\begin{tabular}{|c|c|c|c|}
\hline Program & Program Goals & $\begin{array}{l}\text { Pre-departure } \\
\text { Preparation }\end{array}$ & Assignments Abroad \\
\hline Netherlands & $\begin{array}{l}\text { Compare the American and } \\
\text { European educational systems } \\
\text { Move from cultural comfort } \\
\text { zones Develop cultural } \\
\text { competence Use technology } \\
\text { for educational purposes Gain } \\
\text { transferable skills and } \\
\text { knowledge while learning } \\
\text { about the option for teaching } \\
\text { internationally }\end{array}$ & $\begin{array}{l}4-5 \text { one to three-hour } \\
\text { whole group meetings } \\
\text { to discuss: } \\
\text { Dutch \& German } \\
\text { education system } \\
\text { American and European } \\
\text { culture } \\
\text { Packing and general } \\
\text { travel information } \\
\text { Former participants as } \\
\text { guest speakers } \\
\text { Lesson planning } \\
\text { Creating and building } \\
\text { Facebook page for } \\
\text { program communication } \\
\text { Transferable goals } \\
\text { discussion \& selection } \\
\text { video log }\end{array}$ & $\begin{array}{l}\text { 3-hour alone } \\
\text { experiences with video- } \\
\text { log reflection } \\
\text { (Disequilibrium } \\
\text { triggering experiences) } \\
5 \text { inquiry assignments } \\
\text { composed of a question } \\
\text { about culture or } \\
\text { education to be } \\
\text { answered through the } \\
\text { inquiry process (Critical } \\
\text { to frame of reference) } \\
\text { One synthesis } \\
\text { video/digital story as a } \\
\text { culmination of the } \\
\text { experience } \\
\text { (Transformative change, } \\
\text { plans, actions) } \\
\text { Post assignments to } \\
\text { program Facebook page } \\
\text { (Transformative change, } \\
\text { plans, actions) }\end{array}$ \\
\hline
\end{tabular}




\begin{tabular}{|c|c|c|c|}
\hline Peru & $\begin{array}{l}\text { Compare the American and } \\
\text { Peruvian educational systems } \\
\text { and ecosystems Develop } \\
\text { appreciation for Peruvian } \\
\text { culture Move from cultural } \\
\text { comfort zones Develop } \\
\text { cultural competency Gain } \\
\text { transferable skills and } \\
\text { knowledge while learning } \\
\text { from international scientific } \\
\text { endeavors }\end{array}$ & $\begin{array}{l}5 \text { two-hour whole group } \\
\text { meetings ( } 2 \text { hour) to } \\
\text { discuss: } \\
\text { Briefing by Office of } \\
\text { International Travel } \\
\text { Program overview and } \\
\text { packing } \\
\text { Peruvian culture with } \\
\text { guest speaker } \\
\text { Three Basic Spanish } \\
\text { sessions } \\
\text { Student presentations of } \\
\text { required readings } \\
\text { Intro to art craft } \\
\text { Designing lesson for all } \\
\text { day English and ecology } \\
\text { fair }\end{array}$ & $\begin{array}{l}\text { Implementation of } \\
\text { lessons developed for } \\
\text { all-day Environmental } \\
\text { Education "Feria" (fair) } \\
\text { in English at a free } \\
\text { access non-profit school } \\
\text { near Lima for K-11 } \\
\text { students } \\
\text { (Disequilibrium } \\
\text { triggering experiences) } \\
\text { Participation in lectures, } \\
\text { group tours, \& group } \\
\text { jungle hikes } \\
\text { (Disequilibrium } \\
\text { triggering experiences) } \\
\text { 12 daily reflective } \\
\text { journals on cultural, } \\
\text { wildlife, and } \\
\text { environmental } \\
\text { experiences (Critical to } \\
\text { frame of reference) } \\
\text { 'Unpacking' in whole } \\
\text { and small discussion } \\
\text { groups (Critical to } \\
\text { frame of reference) } \\
\text { Short essay as a } \\
\text { culmination of the } \\
\text { experience collected } \\
\text { into online book } \\
\text { (Transformative change, } \\
\text { plans, actions) }\end{array}$ \\
\hline
\end{tabular}

Case study participants $(n=5)$ were purposefully selected from our study population $(\mathrm{N}=93)$ to represent a varied cross section of teacher demographics. Three participants are White; two are from a marginalized race and/or ethnicity (Mixed Race and Latina). Three identify as female, two as male. Participants range in teaching experience from 1-6 years, teach at levels ranging from elementary to high school, and teach in a variety of areas (Table 2). 
TABLE 2

CASE STUDY PARTICIPANTS

\begin{tabular}{lllllcc}
\hline Name* & $\begin{array}{l}\text { Sex/ } \\
\text { Race/Ethnicity }\end{array}$ & Program & Age & $\begin{array}{c}\text { Current School/ } \\
\text { Grade }\end{array}$ & $\begin{array}{c}\text { Years } \\
\text { Taught }\end{array}$ & $\begin{array}{c}\text { Years } \\
\text { Since } \\
\text { Program }\end{array}$ \\
\hline Lucia & F/ Latina & Peru & 28 & $\begin{array}{l}\text { Urban Middle/ 6th } \\
\text { grade Science }\end{array}$ & 5 & 5 \\
Jessica & F/ White & Peru & 27 & $\begin{array}{l}\text { Urban Charter Elem/ } \\
\text { 4th grade }\end{array}$ & 6 & 6 \\
Paul & M/ White & Netherlands & 27 & $\begin{array}{l}\text { Suburban High, } \\
\text { Special Education }\end{array}$ & 5 & 6 \\
Faith & F/ White & Netherlands & 22 & $\begin{array}{l}\text { Rural Elementary, 3rd } \\
\text { grade }\end{array}$ & 1 & 1 \\
Devon & M/ Mixed Race & Netherlands & 27 & $\begin{array}{l}\text { Urban High/ 9th } \\
\text { grade }\end{array}$ & 3 & 8 \\
\hline
\end{tabular}

*Note: All names are pseudonyms

The data sources included field notes, prior knowledge of participants, and semi-structured postinterviews. The interview assisted in capturing participants' long-term cultural awareness, reflection, and pedagogical actions in response to the teacher education study abroad. Ten a priori codes were determined that aligned to transformational learning theory and CPP (Table 3). Dedoose software was used to analyze data and assist in the coding process. The coding process was iterative and included three rounds of coding check-ins and pattern finding. Through the triangulation process, codes and themes emerged, and common definitions of terms and codes were discussed and determined using the theoretical framework.

TABLE 3

CODING MAP

\begin{tabular}{|c|c|}
\hline A priori Parent Codes & Case Study Themes \\
\hline 1. Increased Cultural Awareness & Critical Frame of Reference/Deconstruct \\
\hline $\begin{array}{l}\text { 2. Knowledge and Skills } \\
\text { i. Cultural } \\
\text { ii. Pedagogical } \\
\text { iii. Higher tier }\end{array}$ & Deconstruct/Reflect \\
\hline 3. Identity Transition and Skills & Identify/Deconstruct \\
\hline 4. Seeking out cultural experiences & Perform/Pedagogy/Action/Re-imagined Future \\
\hline 5. Taking Cultural Action & Perform/Pedagogy/Action/Re-imagined Future \\
\hline 6. Challenging Own Culture & Deconstruct/Analyze \\
\hline
\end{tabular}




\begin{tabular}{ll}
\hline 7. Connection to Place & Identify/History/Context \\
$\begin{array}{l}\text { 8. Culture of Origin } \\
\text { iv. Subculture USA }\end{array}$ & Identify/History/Context \\
$\begin{array}{l}\text { 9. Recognized by Others } \\
\text { v. Culturally }\end{array}$ & Identify/History/Context \\
10. Reflection & Reflect/Analyze/Reimagined Future \\
\hline
\end{tabular}

\section{FINDINGS}

Analysis of data revealed that the most frequent effect our participants experienced was increased levels of cultural awareness after their teacher education study abroad experience (Table 4), but their international experiences had slightly different meanings for each of them.

TABLE 4

TOP FIVE MOST FREQUENTLY CODED THEMES

\begin{tabular}{lccccc}
\hline Participant & $\begin{array}{c}\text { Increased } \\
\text { Cultural } \\
\text { Awareness }\end{array}$ & $\begin{array}{c}\text { Cultural } \\
\text { Knowledge \& } \\
\text { Skills }\end{array}$ & $\begin{array}{c}\text { Pedagogical } \\
\text { Knowledge \& } \\
\text { Skills }\end{array}$ & $\begin{array}{c}\text { Identity } \\
\text { Transitions }\end{array}$ & $\begin{array}{c}\text { Culture of } \\
\text { Origin }\end{array}$ \\
\hline Lucia & 14 & 8 & 11 & 8 & 7 \\
Jessica & 9 & 1 & 3 & 1 & 4 \\
Paul & 6 & 9 & 2 & 11 & 6 \\
Faith & 19 & 8 & 12 & & 2 \\
Devon & 18 & 16 & 14 & 5 & 3 \\
\hline
\end{tabular}

In the five case studies, we trace each participant's teacher education study abroad experience through from their trip to their current teaching experiences using our theoretical framework structure for narratives: study abroad triggering event(s); identification and/or deconstruction of an injustice; critical analysis from a new frame of reference; a re-imagined better future and any action towards the same. Many had disorienting experiences that had them take on a critical view during immersion that challenged their prior assumptions and practices that they had taken for granted in the dominant culture in the USA. This helped them to analyze for themselves, teaching in culturally diverse classrooms, what needed to change in the culturally diverse classrooms, in which they taught. They reported acts, either pedagogical or personal, which evidenced seeds of varied forms of cultural competence in their pedagogy; acts that sought to have a positive effect on the social and ecological place they inhabit (Gruenewald, 2003). 


\section{Lucia}

... in the jungle, in the actual rainforest, and experiencing that firsthand--it changes your perspective on life, and on the world. And it definitely ... It's affected my teaching. And then as far as the city part, going and working with that population of kids, it also just changes your view on education. -Lucia

A disorienting experience for Lucia was when she was thrust into the position of language and cultural interpreter for her peers while abroad, even though she had never been to Peru. Although she had emigrated to the United States as a child from Colombia, the culture of Peru was a new one for her. She found herself negotiating between her discovery of a different, albeit similar, culture and her deep understanding of the Hispanic Latin American culture. She used her existing life skills to navigate interpreting culture and language in order to help support her classmates who did not speak Spanish and/or had never been to a Latin American country before. Those who did not speak Spanish were especially challenged when we were teaching children at a local school; yet, this was not a challenge for Lucia but rather served as an opportunity for growth. "I think it definitely put me in a leadership position in the group, just because a lot of times people ... I can empathize with people not knowing any of the language whatsoever, and feeling completely lost. So, it did help a lot being able to speak the language" she said, ". . [ [to] connect with the kids, just because I was able to have actual conversations with them, instead of just trying to figure out what [they're] saying"

Near the end of the trip, as we traveled towards the airport from our riverside lodge deep in the Manu jungle area of Peru, we were surprised to find that on one leg of the trip back, while crossing a land bridge between rivers, the arranged bus was not there waiting for us as we disembarked from the river canoes. There was a string of jeeps lined up as a substitute. Lucia was quickly assigned as the designated Spanish interpreter for one of the jeeps. Each jeep had a university faculty or staff, a Spanish interpreter if they did not speak Spanish, and two or three more people from our group in the car, along with the Peruvian driver. Lucia's assigned role, assigned to an undergraduate preservice teacher abroad in this extremely remote area of the jungle, involved an important responsibility that we needed for her to take on. Had that jeep been separated from the group for any reason she would have had to take on a co-leadership role along with the faculty/staff who would have depended upon her cultural knowledge and Spanish interpretation during any delay or other unplanned situation. Although nothing unexpected happened, we all arrived together, the role was no less serious in importance. She said that sometimes she was thrust into the role of leader "by default." She continued, "Like you were saying, some of the other people you could tell that they didn't speak the language in the group, and you did. It's like by default they would turn to you, and say, 'What did they say?' So, you sort of by default become a leader, because you're bilingual. It becomes a necessity, something that's necessary to the survival of the group."

Her cultural positionality in Peru was at the reverse end of the social hierarchy ladder when compared to her cultural positionality while in the USA. She went from being minoritized as an immigrant from another culture who did not speak English perfectly while at university in the States, to being admired by peers for being culturally competent in Spanish and the dominant Hispanic Latin American culture while they were in Peru. The political climate in the southeastern state she had grown up in and studied in was becoming increasingly anti-Latino, and at home being an immigrant speaking Spanish in public, or at school to students, could often be discouraged. Her Spanish interpretation skills in the USA were not recognized as valuable to the group, not as they were recognized once we were in Peru. These skills were made visible while the cohort was abroad, where the dominant culture and language was Hispanic/Spanish. In reflection, Lucia recognized that this was what happened, that she felt she was needed for her culture of origin by her peers.

Through reflection over time Lucia realized that her experiences in the Manu jungle in Peru included not only learning about the dominant Peruvian culture as a Colombian-American visitor and how to be that cultural bridge person for her peers; she learned that there were marginalized cultures in Peru too. She participated in watching and then in small group discussion related to a documentary about a local tribe 
from the Peruvian jungle protesting the commercial use of their lands. This experience introduced Lucia to a new awareness that there exist peoples native to the wilderness in the rainforest that live outside of the dominant Hispanic American culture in Latin America.

As a middle school science teacher, before she finished her Master's degree to take on a job as assistant principal, Lucia took on a role as school interpreter on behalf of students whose parents spoke Spanish at the large middle school where she worked. This was a position of responsibility among staff. "I'm the only Latina. I'm the only one that can speak Spanish," she said. She also knew first hand what an immigrant can go through when they arrive as a child in the USA, and of the challenges of living in a world full of cultural differences. With reference to her role as a teacher she said, “. . . if I don't know anything about their culture, it's very hard. Yes, I can go ahead and learn it."

Lucia not only sought out new cultural knowledge about her students to better understand where they were from, doing things like going to cultural food fairs, she realized that she had become aware of nuances in cultural differences between herself and her "newcomer" immigrant students. She realized one of her students, a new immigrant from a Spanish-speaking Central American country, who others may have assumed was a native Spanish speaker, spoke an indigenous first language and did not speak Spanish. She noted, "I think being able to connect with those [immigrant] students [in my classes] in a more meaningful way had a lot to do with my trip to Peru."

\section{Jessica}

I think it definitely gave me a better, a broader perspective, and an appreciation for travel, but also for different cultures, different ways of life. -Jessica

For Jessica, Manu, Peru was her first trip abroad. Not only was the place new to her, so was the experience of international travel. Her outstanding memories were of teaching Environmental Education (EE) lessons in English at a K-11 school for children from low-income families just outside of Lima and all the types of transportation we took on the trip. The transportation put her out of her comfort zone.

All the different modes of transportation we used [stood out], especially where we were, we took the canoes ... I can see it in my head where we had the cabins outside ... And then we were on one of the buses and there was a landslide, so we were stuck there. That was definitely hard because I was like, "Oh no, what are we going to do?

Jessica recounted that being without her cell phone also put her out of her comfort zone, she had not been without it before the trip to the Manu jungle.

When I first told my parents about it, and I told them I didn't really know about cell phone reception, or Internet, and actually just decided to leave my phone at home. It was interesting because they weren't necessarily happy about it ... So, I think for me it was as much technology that we need today and have, [as] it was an opportunity to really disconnect and limit that. And so, it kind of gave me a different perspective of people that don't have it a whole lot. And that it is doable.

Jessica had disorienting events in which she noticed cultural differences initially, in the school visit and during travel in the more remote regions of Peru. Visiting the school in Lima, Jessica realized some differences in Peruvian culture, such as how students gathered at their school lunch cooked by their parents, and at the same time, she noticed that the family gatherings were somewhat similar to what we do in the US. She did not mention any injustices in what she saw. Visiting the jungle, she participated in forms of travel that were new to her, and destabilizing. These were triggering experiences that can lead to transformation towards cultural competency. 
She reflected upon the trip to Manu as it pertains to her work as an elementary school teacher working near where she grew up in a small-town area of a southeastern state. She mentioned the wildlife from the jungle, and that is what she said she talked about with her students. "I've shared some pictures and we've talked about it". When reflecting upon cultural aspects of how the trip affected her, she mentioned that due to the ethnic/racial makeup of her schools' student population she is challenged to identify who may or may not be immigrants in her diverse classroom. While she felt the trip changed her by making her more interested in other cultures, she was not aware of which of her students were Latin American immigrants in her classroom. She said, "I think too, sometimes you know, the students in fourth grade maybe they don't really want to talk about it, or share as much you know, putting [out] private information to their peers, some of it."

Jessica was from and worked in a small Southeastern town and admitted that she did not seek out new cultural experiences after the study abroad program. She did, however, feel that the trip to Peru definitely broadened her perspectives, and as she said, "it gave me a different outlook, and a different, I guess, appreciation for what we have--and also a respect for other people and in their culture." She noted that her broadened perspectives "can be applied, of course, in the classroom, and students, and their family". Jessica was out of her comfort zone in Peru when she had to leave behind her cell phone, and in the kinds of transportation we took into the jungle, and these were her disequilibrium triggering experiences consuming her energy while in cultural immersion, and though she had to deal with all of this, she still felt that she had developed a different outlook that included a respect for other people and their culture.

\section{Paul}

New place, new people, new experiences, all things I haven't done. So, until you do something, you can't have a ton of confidence in it. And just being put there and doing it just adds to your life experiences; that kind of makes you who you are. You're a culmination of everything that you've done in life. So, if you're adding new things, then you're changing as a person. -Paul

Paul had a particular interest in Dutch specialized schools and how their system uses tracking for students with learning challenges when he participated in study abroad as a preservice teacher. During the teacher education study abroad trip, and his observations of special education teachers in the Netherlands, he was skeptical of tracking and the lack of inclusion that schools provided. After study abroad and after working as a special education teacher with years of experience educating students with learning challenges, he told us how he began to analyze the observed situations in the Dutch specialized school and the United States with a critical teacher's perspective; his study abroad experiences served as a critical frame of reference. He was starting to compare what he was experiencing to what he had learned about and experienced during his two study abroad experiences in the Netherlands, first as a participant, and again as an assistant to the professor accompanying the group abroad.

I had the experience of their [Dutch] tracking, different special education schools or tests that you have to take and get tracked in different high schools. Things of that nature. And then now being a special education teacher I'm still undecided on what the best route is. If you ask me right now, I would probably think that tracking would be a better outcome for our students because right now I'm forcing a lot of [autism spectrum disorder] ASD students and students that are not capable in my opinion to take classes that they're not meeting the standards in, and we're just passing them through because what else are we going to do? So, we can just say, "Okay, they just get a passing grade, a C." Or we can say, "Okay, I'm going to accommodate all this stuff, but is it really still meeting the standards that everyone else has asked to get?" 
With increased global cultural awareness through his exposure to the special education program in the Netherlands, he was willing to challenge his own culture, “. . . I've gone with numbers of my department, with my own union and keep pushing leadership to, hey, we need more help. We're not lazy teachers. We need another teacher because we're overwhelmed. I'm teaching six different preps throughout the day. Every class is a different class. And then the administration saying, "Hey, we don't have the money" or whatever. That's basically what they're telling us. That forms my kind of views a little bit too." Paul mentioned the challenges he faced with students on the Autism Spectrum; he thought that specialized schools focused on skill development like they have in the Dutch school system would assist his students that struggled to meet the standards in general classes in the United States.

He recognized that he was in some ways more close-minded before his study abroad and that now he is ". . . more of an open-minded global citizen, I would say, because it can be easy to just think about the city or the state you're in; and then now thinking more on global issues has definitely influenced how I think about what's going on in the world today." He engages in globally-minded critical reflection. He referred back to the visit to the refugee school, and compared it critically to the current situation for immigrants to the United States at the time of his interview.

When I think about refugees, I kind of think of their experiences and stories they told us. And that will always have changed my life because it's obviously a topic that we hear. Every day we got this caravan coming. Those are kids and women and they're coming from a different country, but they're doing the same thing that these kids were doing and experiencing a lot of similar experiences. So I would say, yeah in that way when I think of refugees, I think about the kids that we met and the stories that they told. Not that I have any specific [stories] that stand out, but just remembering the emotions that brought out in me and feelings of empathy. I can empathize better.

Paul saw problems in what he does, in part due to his increased cultural awareness, problems that others may take for granted as inescapable. "There's only one diploma in the state ..." he said, And the fact that there is no tracking at his school, as he observed in Europe for special education giving students multiple options, left him with a constant lingering cognitive comparison. "So, I have a moral dilemma on my hands almost every marking period. Does this kid earn a diploma or does this kid not?" Rather than offering other options, he can only offer one high school diploma program. Despite this limitation, he saw solutions. Instead of a one size fits all solution, Paul's re-imagined future included the idea that students with learning challenges have many options. These options would benefit children beyond the typical academic diploma. He also told us that he encouraged his special education students to travel.

I constantly am telling my kids there's a bigger world outside of this, and what you think right now is important is important to you right now, and I understand that, but you've got to think down the line. . Just trying to give them the perspective that it's not as deep as you think it is, and the test score that you have right now is not going to impact you in the next 10 years. Travel and meet new people and experience life.

Paul went on to earn his Master's degree after graduating with his undergraduate urban cohort teaching degree and spoke of his confidence to be able to make a positive difference. Paul said, "I would say I would definitely be more culturally competent" after his preservice teacher education study abroad experiences. "I definitely think it changed my life. I was able to go."

\section{Faith}

I did not know a lot about other cultures. I really just stuck to myself, stuck to the American way. I didn't really care to know other cultures, until we went abroad. And then I'm like "Oh, I've picked this up from there. I've picked this up," and it really opened my eyes to 
things that other places do... My eyes had been opened, literally, to so many different new cultures and things that they do that we don't here. -Faith

Faith had traveled extensively in Latin America before going on the trip as a preservice teacher to the Netherlands. What she mentioned as important in her memories from the trip was the Dutch refugee school visit--it was transformative for Faith.

I think the most important thing, the one that stood out the most, is going to the refugee school. Just because that was the climax, the height of my trip. It really changed my perspective and my view on refugees, because growing up I was taught to know that they were bad. All of them. Didn't matter who they were, where they were from. We don't let them in, cause they're not good'. After we went to that school, I was like "They're just like me!" They're not any different than I am. So, why are we not helping them?" It really changed my entire perspective; and it made me really more open to other people's views and opinions and things like that.

She brought to the refugee school visit her own personal history and experiences. Her thoughts and feelings about refugees before the experience were more hands-off. She commented about the people who are refugees and about her changing perspectives on refugees. After talking with one of the refugee students about wanting to be re-connected with family, she said, "I was always standing back like 'They'll take care of it, someone will take care of them.' But now I'm like, 'Yeah, let's do it. Let's help them as much as we can." She began to realize the difference between how she was taught about refugees in the US and how her experiences with individuals, hearing their unique experiences, she saw an opportunity to step in herself. As she said, "But now I'm like "Yeah, let's do it. Let's help them as much as we can."

After meeting and talking with Alfred, a student from Afghanistan, she became critical of her narrative around refugees in the USA. "I had one instant once home, and I guess it doesn't pertain exactly to the people I met, but it's just my changed view, and he was calling these people "A-rabs" and saying we can't help them, they're all gonna come in here and bomb us. And I looked at him, I was like. "You've got it all twisted around. Those people aren't the ones that are wanting to come into this country and wanting our help. They're the ones that are gonna keep terrorizing where they're at." But I couldn't change him at all. I couldn't sway his view. I couldn't make him see eye to eye with me. Either he just kept shutting me down, and it's not worth it. I tried, but that's really the only time that I've came face to face with someone about refugees and things like that. It was a rough conversation. I came away steaming mad. I had tears welled up in my eyes, just because the way he was thinking was making me so mad. He wasn't understanding at all."

Through reflection, experience, and deconstruction of her initial understanding of refugees, Faith began to see the similarities between herself and the refugee students. Reflecting upon her cognitive transformation, she said that "a lot of people around here think the same way that I did, and I'd love to change their views" Eventually, Faith defended her new perspectives by speaking up against a racist comment about Afghani people. She engaged in a verbal argument against the racist comment and the assumptions that the person was using to make the judgement about Afghani people. Faith had the courage to take action to support her transformed views. Faith's re-imagined future included a world where Americans were accepting of refugees and had an understanding of the political situations that led people to seek asylum.

Her understanding of education was broadened when she met a teacher from her home state who was working at the American school abroad, and that's how she learned about job opportunities for teachers to teach in other countries, and she now teaches in an American School abroad. "I really didn't know that you could go across the world and teach. I always thought you had to stay here in the States. I didn't know that it was possible to do, so I thought that that was really neat. I liked meeting people from the US, especially in international schools. 
Her broadened cultural awareness translated in her classroom through the conversations she had with her students, conversations that included: listening to others, reflecting on viewpoints, and being accepting of difference. "I like referring back to things that they did, or things that they eat," she said, "I brought up several times in my class [that] we eat this in this country, and that's something that's native to them" and she tells her students, "Now, even in my classroom, I'm like "We don't know how they are, so let's look at it." and "I would just say, [be] more accepting of others. Realizing that there's people out there that are different than me. They're not all from this Southern bubble, that we all think alike and act alike and sound alike. That there's people that are different, and that's okay"

\section{Devon}

...we had gone to what I believe was like a refugee school in the Netherlands, and I had asked a question to one of the students, it was like a high school age student and he was from Iran or maybe Afghanistan. I'd asked him what he wanted to do with his life, once he was finished with school and his translator had looked at me and apologized cause he's like, "he hasn't given it any thought because he never expected to live to this age" so he hadn't considered what to do with a job. Because it was just a foregone conclusion that he was going to be killed in the fighting in his country, so that was a really eye-opening experience for me, and as a privilege that I have and the privilege I think us as Americans, have. There's just so much more going on than what we're privy to on the television or the news, things like that. And how our view is so minuscule compared to the entire people. That was something that really made me check what I bring to the table as far as education and assumptions made about students and individuals and countries, and things like that. Devon

Devon was the youngest participant on the study abroad program. At nineteen years old, he was just beginning his undergraduate program in teacher education. He was focused on teaching in an urban setting because of his experience at a Title I, urban school. While abroad his most memorable experience was his two days at a refugee school in the Netherlands.

A disorienting experience for Devon was a conversation with a refugee student. Devon asked him what he wanted to do with his life after high school. To Devon's surprise, the student's interpreter answered, "He hasn't given it any thought because he never expected to live to this age." This response made Devon aware of injustices, especially around privilege and how privilege creates blinders. After the refugee school visit the group then visited a high-end, affluent International school in the same city. Devon reflected on both experiences and left with a confirmed idea that the socioeconomic gap exists everywhere.

Through reflective analysis, Devon realized his privilege to contemplate the future. That transformative conversation elicited him to deconstruct his views of education and his assumptions about students and other countries. He shared this story with his ninth-grade students. Telling the story helped him discuss privilege which he viewed as being part of his duty as a culturally competent teacher. In turn, making his students comfortable in sharing their stories of cultural differences in his classroom. Panning out to a broader view, he also said, "we have to work as educators globally to figure out how to solve that and how to make sure all students receive that equity in the classroom no matter how much money their school does or does not have. Those are the stories I find myself telling the most people when I mention that I studied abroad."

On the importance of reflection over time, guided reflection, Devon remarked that "So, I think it's kind of like a slow-cooker of ideas. I would be lying if I said when I came back, I was like "Oh it's perfect everything's great now. I'm so much more tuned in to people ideas" and things like that. But I think just sitting and letting it stew a little bit and letting those ideas kind of sit and develop over time has obviously positively changed my life for the better."

Devon took action beyond the classroom doors. He experienced cultures in his community unknown to him. For instance, he attended a Catholic confirmation of one of his students. This experience allowed him 
access to the cultural traditions of one of his students and her family. His action gave him a chance to interact with family members and learn about new religious traditions, providing him with an insider understanding of his student's culture and her life outside of the classroom.

\section{DISCUSSION}

Summarizing positive aspects from the reflective narratives, study abroad impacted all the teachers in lasting and different ways (Table 4). Lucia used her experiences as a teaching tool, and her enhanced cultural awareness to take a leadership role and act as a school interpreter and liaison between the Latin American heritage community for the sake of her students and the school administration, as well as help knowledgeably welcome immigrant students into her classroom. Jessica gained a new interest in cultures other than her own, which could seed culturally competent pedagogy. Paul took on a leadership role on a follow-up study abroad trip, and using his gained knowledge of other nations' school systems as he plans to put in place his re-imagined better future as a school administrator. Faith found courage; she was encouraging her students to see the world, showing them what is possible, and she had an awareness of skewed narratives around people from outside of the USA. Devon gained awareness of his privilege during his visit to the refugee school, something not realized as a mixed-race student in the school where he grew up. He took on the responsibility to provide a comfortable and safe learning environment for his students.

Most of the teachers spoke of how experiences influenced a cognitive transformation, and this supported actions they took since their study abroad, moving them toward their re-imagined better world. Contextual factors affected by her personal history, such as her readiness for change, may have made Jessica less predisposed to a transformational learning experience (Baumgartner, 2001) that would lead to action. Jessica spoke of her taking on the perspective of those who lived in the country she was visiting, those who did not have technology. This idea voiced by Jessica insinuated that although Jessica felt she had gained empathy for Peruvians without phones from her study abroad experience, there may not have yet been a cognitive transformation. The new perspective she spoke of was derived from an underlying conception or stereotype that people in the country we were visiting (Peru) were without technology. This was true for the children from low-income families we met at the school where we taught lessons, but not true for our guides deep in the jungle, or for people we saw and crossed paths with in urban areas.

Jessica was not required to grapple with these inconsistencies to her assumption that people were without cell phones in Peru as part of her reflection. She situated her new perspective of doing without a cell phone within an existing preconception or stereotype that people generally do not have phones in Peru. Had she looked closely at who did have phones in Peru and who did not, and how that reality compared to the ideas she had before traveling, she may have, upon reflection, seen an inequity in technological access for Peruvians according to investment in infrastructure in different places (cell phone towers), the role of public and private industry, pricing, marginalization of certain sectors of the society, and income inequalities--all which would certainly have complicated her newfound perspective and could have promoted a deeper cultural empathy--perhaps critical thinking about former conceptions such as this would even have promoted a cognitive transformation toward cultural competence for her.

Critical thinking which leads to cognitive transformation is a skill that we as teacher educators can promote for preservice teachers who study abroad in cultural and environmental immersion. We can promote this through prompts for reflections. Preservice teachers can develop and transfer the skills of cultural deconstruction and critical thinking that they learn abroad as we encourage them to ask questions such as, "Where were/are my preconceptions? What am I seeing? How do my preconceptions compare to what I observe and understand here in this new place?" Gruenewald (2003) points out that by taking into account situationality we can engage in changing students' relationship with place, in turn leading to dispositional and pedagogical changes.

The preservice teachers also revealed instances of developing CPP, through moments of decolonizing and re-inhabiting (Gruenwald, 2003). Lucia noted how being the rainforest provided a new awareness that changed her teaching; thus, she was starting to deconstruct her pedagogy through the lens of experiencing a different culture firsthand. Paul shared how he was working through the decolonization of special 
education programs in the United States, and he imagined how these spaces could be re-inhabited to provide more equitable opportunities for students to encompass life skills as well as academic learning. Faith went even further and critically reflected upon her own former thoughts of refugees, and she expressed her desire to re-inhabit a place where she could help others also deconstruct their own uninformed views of refugees. Finally, Devon decolonized his own classroom by sharing his personal experience of being confronted by his own privilege; thus, he helped provide a place where his students could share more openly about their personal experiences.

We found some students were ready to take the plunge and risk disequilibrium and destabilizing experiences during study abroad, while others needed a nudge. We found that trip organizers can design programs with critical consciousness learning in mind, as on the Netherlands program. Teachers in this study used immersion experiences when they returned home by sharing stories and using learned awareness, spurring re-imagining, but we did not find consistent evidence of teachers taking action.

\section{PROPOSED FRAMEWORK FOR CULTURALLY COMPETENT PEDAGOGY (CCP)}

In our study abroad programs, students were asked to deconstruct historical and cultural components that lead to unjust systems in society. Students were given an opportunity to dig deeply into another culture and place, but how well were they then prepared to engage actively in critical reflection and application? Therefore, we propose CCP as going beyond responding to or finding relevance in a different culture from a position in the dominant culture--culturally competent pedagogy carves out a rightful presence for marginalized cultures that students may inhabit (Squire \& Darling, 2013; Calabrese Barton \& Tan, 2020).

\section{FIGURE 2}

\section{FRAMEWORK FOR CULTURALLY COMPETENT PEDAGOGY (CCP)}

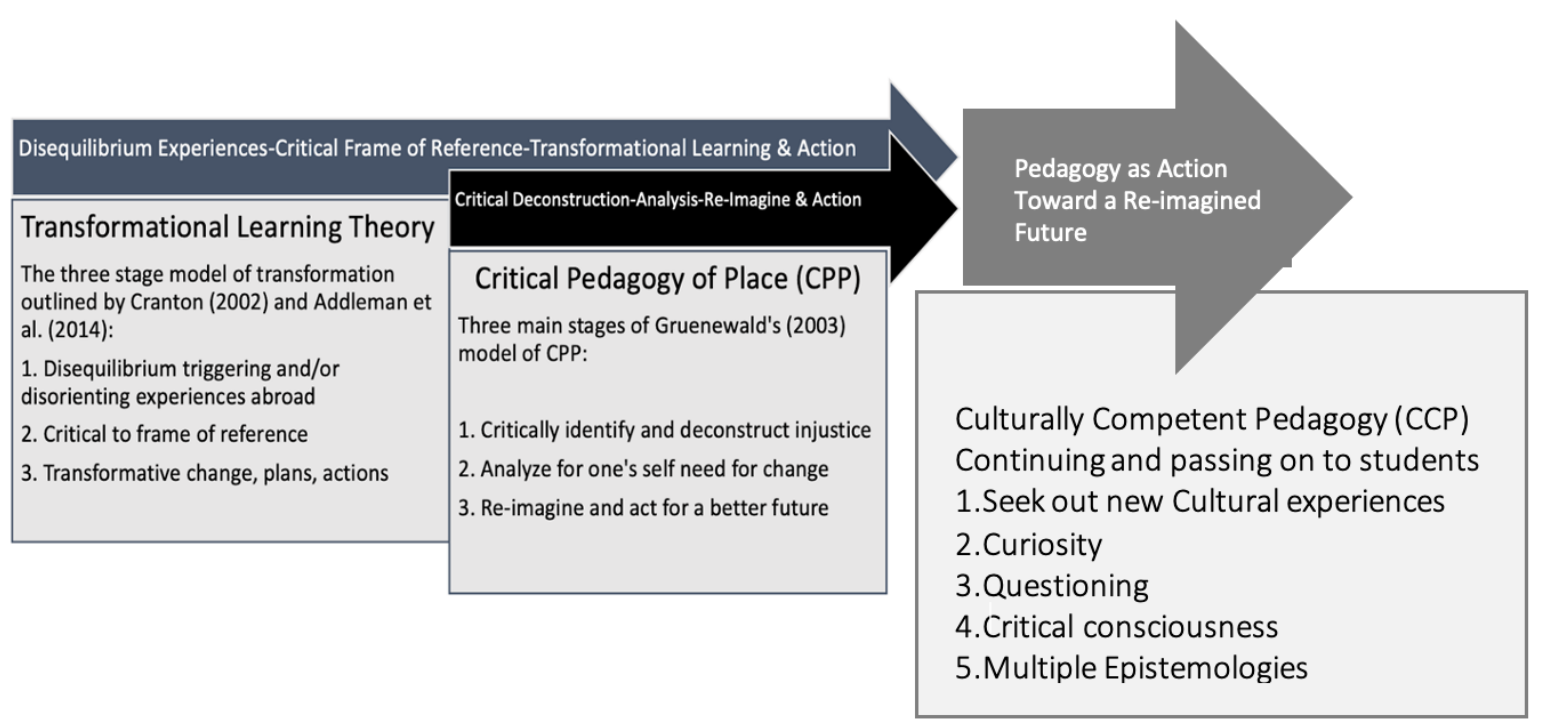

CCP takes a stance that cultural competence is not seen as an endpoint but as a skill set. A culturally competent teacher is used to feeling discomfort in new cultural situations and uses discomfort as a trigger to critically reflect upon what caused the sensation of dissonance, and to critically examine the place and community for any misconceptions or assumptions not in line with real experience. A culturally competent teacher is constantly curious, questions incessantly, and purposefully seeks continuous transformation of self, students, and pedagogy towards a re-imagined future.

We, as teacher educators, can help preservice teachers develop toward pedagogy as action along the pathways indicated in Transformational Learning Theory and Critical Pedagogy of Place. We have 
evidence that these enlightening and transformational moments our participants experienced on the study abroad trips we organized can help push preservice teachers down a pathway towards Culturally Competent Pedagogy (CCP). Pedagogy is, as defined by the teachers we interviewed, an action. Cultural competency is something some of them felt they had developed. Cultural competency, as we interpreted it through the meanings teachers made, is not a static objective, it exists as a state of ebb and flow in response to stimuli and context. It is rather better considered as a state of being in which certain skills through transformational learning and increased critical consciousness are gained, honed and then can be practiced in the future in other contexts--skills which can be passed on to their own students, for their students to then go on to learn to practice in their lives.

In a framework of Culturally Competent Pedagogy (CCP), educators (in the case of this study, preservice teachers) develop new awareness and skills through lived experiences via cultural immersion in study abroad. They can then continue to practice learned cultural competency building skills to increase their cultural understanding. They can seek out new cultural experiences. They maintain curiosity for both new cultures and multiple epistemologies, which are made visible to them through increased critical cultural consciousness, an important component of CCP.

\section{LIMITATIONS}

The findings in this study cannot be generalized and are particular to the study participants. We also have yet to collect data from our participants' classrooms and student work samples to examine more explicitly how they are engaging and developing their students' cultural competence. However, CCP, a theoretical framework which we developed from our findings, is generalizable to teacher education study abroad in cultural immersion.

\section{CONCLUSION}

Although this study is limited to five case studies, we found teachers do not forget cultural awareness gained abroad, and the meanings they made of these experiences influenced the pedagogical practices they engage in. Thus, we as teacher educators hope to facilitate students to continue their growth as culturally competent educators. We as researchers must take responsibility to discover and use the strategies needed to guide teachers to courageous action for their re-imagined futures. In this regard, more empirical work is needed to understand how our participants leverage CCP in their classrooms and how they engage their students in the work of cultural competence. We also need to continue to create spaces within our existing study abroad curriculum to engage students in CCP work, and finally, we plan to develop an interview and observation protocol for CCP that others can use to explore and examine their own programs. For the present, CCP is meant to demonstrate how teacher education study abroad can leverage Transformational Learning Theory and Critical Pedagogy of Place to afford pre-service teachers opportunities to critically reflect upon their world and to re-imagine a future for themselves and for their students that they can all act upon. 


\section{REFERENCES}

Addleman, R.A., Nava, R.C., Cevallos, T., Brazo, C.J., \& Dixon, K. (2014). Preparing teacher candidates to serve students from diverse backgrounds: Triggering transformative learning through shortterm cultural immersion. International Journal of Intercultural Relations, 43, 189-200. doi:10.1016/j.ijintrel.2014.08.005

Baumgartner, L.M. (2001). An update on transformational learning. New Directions for Adult and Continuing Education, 89, 15-24.

Calabrese Barton, A., \& Tan, E. (2020). Beyond equity as inclusion: A framework of "Rightful Presence" for guiding justice-oriented studies in teaching and learning. Educational Researcher, 20(10), 18. DOI:10.3102/0013189X20927363

Cavanaugh, S., \& Corbett, L.J. (2014). A successful model for short-term international teacher education programs. The Field Experience Journal, 1, 1-11.

Chieffo, L., \& Griffiths, L. (2004). Large-scale assessment of student attitudes after a short-term study abroad program. Frontiers: The Interdisciplinary Journal of Study Abroad, 10(1), 165-177.

Chiu, C.L., Sayman, D., Carrero K.M., Gibbon, T., Zolkoski, S.M., \& Lusk, M.E. (2017). Developing culturally competent preservice teachers. Multicultural Perspectives, 19(1), 47-52. DOI:10.1080/15210960.2017.1267515

Cranton, P. (2002). Teaching for transformation. New Directions for Adult and Continuing Education, 2002(93), 63-72.

Freed, A., Benavides, A., \& Huffling, L. (2019). Teaching, reflecting and learning: Exploring teacher education study abroad programs as transformational learning opportunities. In Pedagogy in Basic and Higher Education-Current Developments and Challenges. IntechOpen.

Gruenewald, D.A. (2003). The best of both worlds: A critical pedagogy of place. Educational Researcher, $32(4), 3-12$.

Institute of International Education. (2020). US study abroad, fields of study. Retrieved from https://www.iie.org/Research-and-Insights/Open-Doors/Data/US-Study-Abroad/Fields-of-Study

Kalina, C., \& Powell, K.C. (2009). Cognitive and social constructivism: Developing tools for an effective classroom. Education, 130(2), 241-50.

Malewski, E., Sharma, S., \& Phillion, J. (2012). How international field experiences promote crosscultural awareness in preservice teachers through experiential learning: Findings from a six-year collective case study. Teachers College Record, 114(8), 1-44.

Medina-López-Portillo, A. (2004). Intercultural learning assessment: The link between program duration and the development of intercultural sensitivity. Frontiers: The Interdisciplinary Journal of Study Abroad, 10(1), 179-200.

Mezirow, J. (1997). Transformation theory out of context. Adult Education Quarterly, 48(1), 60-62. doi:10.1177/074171369704800105

Squire, V., \& Darling, J. (2013). The "minor" politics of rightful presence: Justice and relationality in City of Sanctuary. International Political Sociology, 7(1), 59-74. Retrieved from https://doi.org/10.1111/ips.12009 